Canadian Journal of Fisheries and Aquatic Sciences

Canadian Science Publishing Journal canadien des sciences halieutiques et aquatiques

\title{
Can Fishways Mitigate Fragmentation Effects on Great Plains Fish Communities?
}

\begin{tabular}{|r|l|}
\hline Journal: & Canadian Journal of Fisheries and Aquatic Sciences \\
\hline Manuscript ID & cjfas-2016-0466.R1 \\
\hline Manuscript Type: & Article \\
\hline Date Submitted by the Author: & 08-Feb-2017 \\
\hline Complete List of Authors: & $\begin{array}{l}\text { Pennock, Casey; Kansas State University, Division of Biology } \\
\text { Bender, David; Stantec Inc; Kansas Department of Wildlife, Parks and } \\
\text { Tourism } \\
\text { Hofmeier, Jordan; Kansas Department of Wildlife, Parks and Tourism } \\
\text { Mounts, Jessica; Kansas Alliance for Wetlands and Streams; Kansas } \\
\text { Department of Wildlife, Parks and Tourism } \\
\text { Waters, Ryan; Kansas Department of Wildlife, Parks and Tourism } \\
\text { Weaver, Vaughn; SCS Engineers } \\
\text { Gido, Keith; Kansas State University }\end{array}$ \\
\hline Please Select from this Special \\
Issues list if applicable: & $\begin{array}{l}\text { Keyword: } \\
\text { structure, DAMS < Environment/Habitat }\end{array}$ \\
\hline \multicolumn{2}{|c|}{} \\
\hline
\end{tabular}


1 Can Fishways Mitigate Fragmentation Effects on Great Plains Fish Communities?

4 Casey A. Pennock $^{\mathrm{a}}$, David Bender ${ }^{\mathrm{b} 1}$, Jordan Hofmeier ${ }^{\mathrm{b}}$, Jessica A. Mounts ${ }^{\mathrm{b} 2}$, Ryan Waters ${ }^{\mathrm{b}}$,

5 Vaughn D. Weaver ${ }^{\mathrm{c}}$, and Keith B. Gido ${ }^{\mathrm{a}}$

6 Division of Biology, Kansas State University, 116 Ackert Hall, Manhattan, Kansas 66506

$7 \quad{ }^{b}$ Kansas Department of Wildlife, Parks and Tourism, 512 SE $25^{\text {th }}$ Ave, Pratt, Kansas 67124

$8 \quad{ }^{\mathrm{c}} \mathrm{SCS}$ Engineers, 11120 E $26^{\text {th }}$ St N, Wichita, Kansas 67226

9

10

11

12

13

14 Corresponding author: 116 Ackert Hall, Kansas State University, Manhattan, KS 66506,

15 Phone: (620) 213-3067, Fax: (785) 532-6653, Email: pennock@ksu.edu.

$16{ }^{1}$ Current affiliation: Stantec Inc., 6800 College Blvd, Suite 750, Overland Park, KS 66211,

17 email: david.bender@stantec.com

$18{ }^{2}$ Current affiliation: Kansas Alliance for Wetlands and Streams, P.O. Box 5, 421 N. Washington,

19 Cheney, KS, email: jmounts@kaws.org 
Abstract

21 Fishways are a common tool for mitigating the effects of habitat fragmentation on fish, but their

22 utility in low-gradient, sand-bed rivers of the Great Plains is not well studied. The Lincoln Street

23 Fishway on the Arkansas River became operational in 2015 and was built specifically to pass

24 small-bodied threatened fishes. We compared current and historical surveys up- and downstream

25 of the barrier to test the effect of the fishway on community structure and conducted tagging

26 experiments to test the ability of fishes to move into and through the fishway. Differences in

27 community structure and species richness between communities up- and downstream of the dam

28 were reduced following construction of the fishway. Surveys within the fishway revealed $74 \%$ of

29 species from the sampled community were using the fishway. Fishes marked with VIE

30 downstream of the dam were recaptured in the fishway, qualitatively showing that small-bodied

31 fishes could move into and upstream within the fishway. We further quantified upstream

32 movement for three species of small-bodied minnow tagged with PIT tags during manipulations

33 of flows through the fishway. Our results illustrate the potential for fishways to mitigate the

34 effects of habitat fragmentation on fishes in sand-bed rivers. 

networks and prevent the upstream dispersal of fishes have resulted in reductions in populations across the Great Plains (Luttrell et al. 1999; Perkin and Gido 2011; Pennock et al. 2017). Dams in the Great Plains have caused changes in community structure through habitat alteration and

41 interruption of recolonization events which, over time, result in extirpations (Winston et al. 1991;

42 Gillette et al. 2005; Perkin and Gido 2012). The reproductive ecology of Great Plains fishes that

43 evolved under harsh environmental stochasticity makes them particularly affected by

44 fragmentation. For example, long-distance movement is often necessary to migrate from drying

45 habitats during drought and serves as a means of repopulating upstream reaches during flooding

46 (Fausch and Bestgen 1997; Dodds et al. 2004). Several small-bodied minnows endemic to the

47 Great Plains also have evolved a reproductive strategy whereby they release and fertilize eggs

48 into the water column (i.e., pelagic-broadcast spawning) during seasonal spates (Moore 1944;

49 Hoagstrom and Turner 2015). As they develop, fertilized eggs passively drift downstream in 50 suspension above the constantly shifting substrate over a period of several days (Bottrell et al.

51 1964). This reproductive strategy requires extensive migrations to disperse into upstream habitats

52 and subsequently long, intact reaches of free-flowing river to allow eggs to hatch and larvae to

53 fully develop as they drift downstream (Cross et al. 1985; Dudley and Platania 2007; Wilde and

54 Durham 2008). The presence of dams blocks both upstream colonization of drying habitats as

55 well as migrations back to spawning habitats by pelagic spawning minnows. Research is

56 necessary to develop and evaluate creative solutions to mitigate the ecological consequences

57 associated with dam construction (Fullerton et al. 2010; O’Hanley et al. 2013). 
Although building fishways allowing fish to swim around dams has been in use for more

59

60

61

\section{2}

63

64

65

66

67

68

69

70

71

72

73

74

75

76

77

78

79

80

than a century, there remains a large gap in our knowledge of the effectiveness of fishways in restoring connectivity for non-salmonid, small-bodied (i.e., $<100 \mathrm{~mm}$ total length) species. This is especially the case in low-gradient, sand-bed rivers found in the Great Plains (Ficke and Myrick 2007). We are only aware of two studies conducted in this region, and both assessed the use of rock-ramp style fishways. Archdeacon and Remshardt (2012) documented successful use of a rock channel-type fishway by Rio Grande Silvery Minnow Hybognathus amarus on the Rio Grande in central New Mexico. Ficke and Myrick (2007) evaluated community use of a rockramp fishway on the St. Vrain River in the front range of Colorado, but did not recapture any marked fish upstream that had moved through the structure. Despite the sparse information on the effectiveness of fishways in the Great Plains, several studies of fishway passage by nonsalmonids exist elsewhere in the world (Stuart et al. 2008; Pompeu et al. 2012; Benitez et al. 2015). Studies from river systems in Australia document community use of multiple fishway designs in low-gradient rivers (e.g., Gilligan et al. 2003; Stuart et al. 2008). For example, Stuart et al. (2008) reported the successful ascension of a vertical-slot fishway by 11 species with individuals ranging in total length from 21-1030 $\mathrm{mm}$. Given the potential for fishways to mitigate effects of fragmentation, there is a need to better understand the role these structures can play in regions such as the Great Plains because of the recognized importance of restoring connectivity for entire riverine communities (Benitez et al. 2015).

By increasing our understanding of the effects fishways have on fish communities, we can inform management decisions on best practices to conserve species in areas such as the Great Plains that are affected by anthropogenic alterations. The efficacy of a fishway on a Great Plains river might differ from the same design aimed to pass salmonids on a high-gradient 
81 stream. Great Plains rivers typically consist of an alluvial sand-bed, have highly stochastic flow

82 patterns, and are home to many small-bodied species (some endemic to the region) that have

83 lower swimming and jumping abilities relative to large-bodied diadromous species. The

84 objectives for this study were to: 1) compare fish community structure and species richness upstream and downstream of a dam on the Arkansas River in Kansas before and after construction of a fishway, 2) characterize temporal and spatial patterns of species occurrence, abundance, and size structure within the fishway, 3) determine if downstream fishes are moving into the fishway, and 4) assess the movement patterns of small-bodied minnows (Family: Cyprinidae) within the fishway across a gradient of flows. through Colorado, Kansas, Oklahoma, and Arkansas before joining the Mississippi River. Upon entering Kansas, the Arkansas River channel remains predominantly dry between the Colorado border and Great Bend, KS in the central part of the state because of water diversions and groundwater extraction (Cross et al. 1985). The perennially flowing portion of the Arkansas River from Great Bend, KS to Kaw Reservoir (7 082 ha) in Oklahoma is divided into three

97 fragments by low-head dams (Figure 1). The fragment upstream of Wichita to Great Bend is approximately 180 river kilometers (rkm), the fragment running through Wichita is isolated by

99 two low-head dams, $9 \mathrm{rkm}$ apart, and downstream of Wichita approximately $140 \mathrm{rkm}$ flows freely before the river enters Kaw Reservoir, Oklahoma. The Lincoln Street Bridge in the City of

101 Wichita was first built in 1970 and included an inflatable dam attached below the bridge to 102 control water levels in the Arkansas River as it flowed through downtown portions of the city. 103 The dam was built for beautification of the river as it runs through downtown Wichita (Pennock 
104

105

106

107

108

109

110

111

112

113

114

115

116

117

118

119

120

121

122

2017). A permanent, low-head concrete structure replaced the inflatable dam in 1976.

Construction began in 2010 to replace both the bridge and dam because of structural deficiencies. The new bridge and dam were built separately and include a $140 \mathrm{~m}$ long fishway on either side of a central boat passage (Figure 2). The dam is a run-of-the-river structure that is made up of four individually controllable panels that can be hydraulically raised and lowered to control water levels upstream and discharge within the fishway and boat passage. The fishways are both of a Dutch Pool and Orifice design (Boiten and Dommerholt 2006) that consist of 11 concrete weirs with 88 steel baffles, each with an orifice $(0.2 \mathrm{~m} \mathrm{~W} \mathrm{x} 0.3 \mathrm{~m} \mathrm{H})$ that is approximately $0.2 \mathrm{~m}$ up from the bottom of each baffle. The weirs consist of baffles grouped into sets of eight with orifices alternating from right to left, creating a sinuous flow pattern. There are 77 pools on each side of the fishway. The slope of individual weirs is highest towards the upstream exit of the fishway (4.1\%) and decreases towards the downstream entrance $(2.5 \%)$.

The fishway at the Lincoln Street Dam was designed and built for the targeted passage of several small-bodied (Maximum total length: 64 - 150 mm; Kansas Fishes Committee 2014) species of conservation concern and is currently the only fishway in the state. Several high flow events (peak discharge: $419 \mathrm{~m}^{-3} \mathrm{~s}^{-1}$ ) occurred in the two years following completion of fishway construction causing damage to the structure. Final repairs were completed in January 2015, thus the fishway became fully operational only a few months ahead of the beginning of contemporary sampling efforts.

Community Sampling-Pre-fishway and contemporary fish community data were used to assess the influence of the fishway on upstream and downstream community structure. The City of Wichita (hereafter, the City) conducted fish community sampling of the Arkansas River as part of a water-quality monitoring program from 1991-2008 (V. Weaver, unpublished data; 
127 Weaver 1993). One site was sampled $7 \mathrm{rkm}$ upstream of the Lincoln Street Dam in 1991 and

1995-2000. Two sites were sampled downstream of the dam, the first was located $300 \mathrm{~m}$ downstream of the dam (sampled in 1991 and 1994-2008) and the second was located $3 \mathrm{rkm}$ downstream of the dam (sampled in 2002-2004 and in 2006). All sites were sampled from one to four times per year and were located within $2 \mathrm{rkm}$ of contemporary sampling locations.

Contemporary sampling was conducted at 12 sites distributed from 0 to $5 \mathrm{rkm}$ upstream and downstream of the dam and fishway at $1 \mathrm{~km}$ intervals. Sites were sampled once per month in 2015 and 2016 during March, May, June, July, August, and October. We sampled wadeable portions of a site using a seine $(4.6 \times 1.8 \mathrm{~m}, 3.2 \mathrm{~mm}$ mesh $)$ and limited our time at a site, including fish processing, to no more than $1.5 \mathrm{~h}$. The first three sites upstream of the dam are impounded during normal dam operations and consist of a homogenous u-shaped channel lined with rip-rap on both banks. Due to the coarse, rip-rap substrate we sampled $100 \mathrm{~m}$ of shoreline using a combination of backpack electrofishing (Smith-Root LR24, 100-170 V, Freq: 60, Duty Cycle: 30) and seining where possible (i.e., if wadeable). If surveys occurred when the dam was lowered (e.g., for maintenance upstream), we sampled using seining only as at other sites. The first site upstream of the dam started at the exit of the fishway. The first site downstream of the dam was located approximately $500 \mathrm{~m}$ from the dam face where the first consistently forming sand-bar reappeared; the point where the river regained its natural pattern of sand-bar formation. Collected fishes were identified to species, counted, and total length (TL) measured for up to 30 individuals of each species per site.

We tested for differences in observed and rarified species richness among communities up- and downstream of the fishway separately for both time periods with a One-Way ANOVA. Observed richness was calculated for each site at each sampling date. We considered these 
150 samples to be independent because turnover was high across space and time. Rarified richness

151 was calculated using a sample size of 100 individuals. Differences in size-structure upstream and

152 downstream of the dam for the three most common species (i.e., cumulative relative abundance $>$ 153 90\%), Red Shiner Cyprinella lutrensis, Emerald Shiner Notropis atherinoides, and Sand Shiner

154 N. stramineus, collected during contemporary sampling were tested with a Kruskal-Wallis

155 ANOVA. To avoid inflating the power of statistical tests, we used mean length of each species

156 for each visit to a site as our sample unit (Neumann and Allen 2007). We analyzed community

157 structure upstream and downstream of the Lincoln Street Dam prior to and after fishway

158 construction with a Bray-Curtis (B-C) dissimilarity index (Bray and Curtis 1957) using $4^{\text {th }}$ root

159 transformed abundance. Due to differences in sampling methodology, community structure was

160 not directly compared between pre-fishway and contemporary sampling periods. To avoid

161 erroneous results due to differences in sampling methodology during contemporary sampling we

162 analyzed community structure including all samples first, and also excluding samples from the

163 three sites directly upstream of the dam. We used permutational multivariate analysis of variance

164 (pMANOVA, $N=10,000$ iterations; Anderson 2001) on B-C dissimilarities to test the effects of

165 location (i.e., up- or downstream) on fish community structure. We visualized differences in

166 community structure among locations using non-metric multidimensional scaling (NMDS)

167 ordinations. All analyses were completed using the vegan: Community Ecology Package, version

168 2. 4-1 (Oksanen et al. 2016) in program R, version 3.3.1 (R Core Team 2016).

169 Fishway Sampling-To evaluate fishway use by different species, we sampled the

170 structure once per month during March (2016 only), May, June, July (2015 only), and August in

1712015 and 2016. Custom nets (0.5 m W x $1 \mathrm{~m} \mathrm{H}, 3.22 \mathrm{~mm}$ mesh) were used to block baffle

172 openings, trapping fish in pools between baffles. Trapped fish were scooped out with a custom 
$173 \operatorname{dip}$ net (0.6 m W x $1.4 \mathrm{~m} \mathrm{H}$ x $0.9 \mathrm{~m} \mathrm{D}, 3.2 \mathrm{~mm}$ mesh). The number of pools sampled varied 174 across sampling events (range: 112-154) due to the downstream end of the fishway filling with 175 sediment. Species identity and abundance were recorded for each pool separately. In 2015, the 176 first 30 individuals of each species from each side of the fishway were measured to the nearest 177 mm TL. However, in 2016, we measured all individuals. the fishway using generalized linear mixed models (GLMM). Richness and abundance were assessed as dependent variables in GLMMs with a Poisson distribution and log-link function (Zuur et al. 2009). We used weir as a fixed effect and month as a random effect. Due to a difference in which months were sampled during 2015 and 2016 each year was modeled separately. We examined residual plots of our data for potential auto-correlation. Turnover was high across samples in space and time, and residual plots showed no evidence of autocorrelation. Thus, we assumed samples were independent. Mixed models were constructed using the lme4 Package, version 1.1.12 (Bates et al. 2015) in Program R, version 3.3.1 (R Core Team 187 2016). Size-structure of common species captured within the fishway, Red Shiner, Emerald Shiner, Sand Shiner, and Bullhead Minnow Pimephales vigilax, was tested using linear regression. We tested if mean lengths of abundant species varied as a function of weir (i.e., if larger fish were more likely to occur higher up in the fishway). Mean length was calculated for each weir across all samples of the fishway, and was then regressed as a function of weir 192 number. move upstream through the high flows of the fishway, we released fish tagged with passive integrated transponders (PIT) tags into the middle of a series of pools (between baffles) of weir 7 
196

197

198

199

200

201

202

203

204

205

206

207

208

209

210

211

212

213

214

215

216

217

218

with an antenna array installed up- and downstream of the release pool (Figure 2). Six stationary antenna (1 m x $1 \mathrm{~m})$ attached to a multiplexing reading station (QuBE-IS1001, Biomark, Boise, Idaho) were spaced out such that the release pool was bracketed by antenna immediately up- and downstream, two antenna were placed at the most upstream and downstream pools, and two antenna were placed at the first pool of the next upstream weir and at the last pool of the next downstream weir. In addition to the stationary antenna, we used a mobile wand antenna attached to a reader (BP Plus portable; HPR Plus reader, Biomark, Boise, Idaho) to scan each pool of the fishway every $2 \mathrm{~h}$ on the side where fish were released. Experimental fish releases occurred at three different water levels (treatments) within the fishway. The City operates the dam at a standard water level upstream, which we used as our baseline treatment. The second and third treatments involved lowering the water level in the fishway by -0.1 and $-0.15 \mathrm{~m}$, respectively. Following methods outlined in Pennock (In press), we tagged between 45-50 individuals from two species to be released during each water level treatment, including Red Shiner and Sand Shiner that ranged in size from 45-78 mm TL with full duplex $9 \mathrm{~mm}$ PIT tags $(9 \mathrm{~mm}$ x $2.15 \mathrm{~mm}$; Biomark, Boise Idaho). We chose these two species because they are some of the most abundant in our study area, and handle PIT tags relatively well for small-bodied minnows (Pennock In press; Pennock et al. 2016). We opted to not use Emerald Shiner in the experiment because we noticed over the course of our study that this species was sensitive to handling stress. We also tagged a minimum of 30 individuals to be released during each water level treatment of Plains Minnow Hybognathus placitus, a threatened species targeted for passage by the fishway, with full duplex $12 \mathrm{~mm}$ PIT tags $(12 \mathrm{~mm}$ x $2.15 \mathrm{~mm})$ due to their larger body size $(65-117 \mathrm{~mm})$.

Plains Minnow were only compared between two water level treatments due to their scarcity in the system. Fish were tagged the day prior to release and held in aerated coolers overnight to 
219

220

221

222

223

224

225

226

227

assess survival and tag retention. Prior to release, fishes were scanned to confirm presence of a PIT tag and measured to the nearest mm TL. Fishes were held in a net in the release pool for a minimum of 5 min to acclimate to flows before being released. Fish detections on antennas were monitored for an $8 \mathrm{~h}$ period after release for each water level treatment. Because of potential vandalism of equipment, $8 \mathrm{~h}$ was the longest we could effectively leave PIT antenna equipment running. During each water level treatment, we measured discharge in the boat passage and the maximum velocity for each orifice to assess how upstream water level affects flows in the boat passage and fishway. The experiment was conducted twice (May and June 2016) and water level treatments were manipulated over three consecutive days.

Movement into the Fishway-To determine if fishes moved from downstream into or through the fishway, we marked all fish species with visible implant elastomer (VIE, Northwest Marine Technology Inc., Shaw Island, WA) captured at three locations downstream of the fishway (i.e., directly below dam/fishway, site 5, and site 4; Figure 1) in July 2015 and August 2016. All fishes were marked at the base of the dorsal fin with a different color for each tagging location. Crews of 4-12 people spent approximately $8 \mathrm{~h}$ at each tagging location. Tagging events occurred one week before standard community and fishway sampling in July 2015 and August 2016. All individuals from surveys taken after the initial tagging in 2015 were checked for marks. Recaptured individuals were measured to the nearest mm TL.

\section{Results}

Community Sampling-Prior to fishway construction, sampling by the City between 1991 and 2008 yielded 87976 individuals representing 46 species (Table 1). Mean observed richness was twice as high downstream as upstream of the dam (ANOVA: $F_{1,39}=19.8, P<$ 0.001; Figure 3A) with 22 species collected only at downstream sites. Rarified richness was also 
242 higher downstream compared to upstream (ANOVA: $F_{1,39}=11.9, P=0.001$ ). All species

243 collected upstream were also collected downstream. Contemporary sampling after fishway

244 construction yielded 123898 individuals and 39 species (Table 1). Eight species were only

245 collected downstream and 5 species only upstream. Mean observed species richness was

246 significantly different up- and downstream of the dam (ANOVA: $F_{1,142}=9.2, P<0.01$ ); albeit

247 only $16 \%$ higher downstream after fishway construction (Figure 3B). Rarified richness was not

248 different between downstream and upstream (ANOVA: $F_{1,142}=0.07, P=0.791$ ).

Pre-fishway community structure was significantly different among upstream and downstream communities, which can be visualized by clear separation in ordination space (pMANOVA: Psuedo $F_{1,39}=11.8, P<0.001, \mathrm{r}^{2}=0.23$; Figure 4A). Contemporary fish communities in ordination space overlapped considerably among upstream and downstream sites, but significant differences still existed after fishway construction (pMANOVA: Psuedo $F_{1}$,

$254142=15.2, P<0.001, r^{2}=0.10$; Figure 4B). Variable and low sampling efficacy at sites 255 impounded by the dam (i.e., 7, 8, and 9) prompted us to reanalyze community structure while 256 excluding these sites, but significant differences still existed among sites upstream and 257 downstream of the dam (pMANOVA: Psuedo $F_{1,106}=7.2, P<0.001, \mathrm{r}^{2}=0.06$; Figure 4C). 258 Community structure differences in contemporary samples were driven strongly by the disparity 259 in Emerald Shiner abundance between upstream and downstream sites (Table 1). Statistical 260 results remained unchanged when all but the two most abundant species, Red Shiner and

261 Emerald Shiner, were excluded. were restricted to only downstream during pre-fishway sampling (Table 1). Most notably,

264 Emerald Shiner was never collected upstream of the dam pre-fishway construction, despite being 
265 266

267 268

269

270

271

272

273

274

275

276

277

278

279

280

281

282

283

284

285

286

287

one of the most abundant species downstream. While they were consistently collected upstream of the dam during contemporary sampling ( $71 \%$ of surveys), their abundance was nearly 20 times higher downstream (ANOVA: $\left.F_{1,114}=23.2, P<0.001\right)$. Emerald Shiners also were significantly larger upstream (ANOVA on Ranks: $H=52.5, P<0.001$ ) and median lengths differed by $14 \mathrm{~mm}$ between upstream and downstream (Figure 5). In comparison, Red Shiner (ANOVA on Ranks: $H=4.01, P=0.05$ ) were marginally smaller and Sand Shiner (ANOVA on Ranks: $H=2.631, P=0.10)$ did not differ significantly in size structure between sites upstream and downstream of the dam.

Fishway Sampling-Sampling of the fishway yielded 39767 individuals and 29 species (Table 1). Four species, Red Shiner, Emerald Shiner, Sand Shiner, and Bullhead Minnow, made up $>95 \%$ of all individuals sampled. Results from GLMM models showed a significant decline in richness and abundance with increasing distance upstream within the fishway $(P<0.001)$. Richness and abundance within the fishway declined over the course of the entire study (Figure 6). Sixty-six percent of all individuals collected in the fishway were caught in May 2015. The average number of individuals declined by more than $90 \%$ in both years with significantly fewer individuals towards the exit (upstream) of the fishway (Figure 6A, B). Average species richness declined by $60 \%$ moving upstream in the fishway in both 2015 and 2016 (Figure 6C, D). Sizestructure regressions were not significant for Red Shiner $(\mathrm{df}=9, P=0.98)$, Sand Shiner $(\mathrm{df}=4$, $P=0.81)$, or Bullhead Minnow $(\mathrm{df}=4, P=0.22)$ although Bullhead Minnow were never collected past weir 6. Mean length of Emerald Shiner increased significantly with distance upstream in the fishway $\left(\mathrm{df}=6, P<0.01\right.$, adj. $\left.\mathrm{r}^{2}=0.82\right)$.

Movement Patterns in the Fishway-Survival and PIT tag retention was high for all three species over $24 \mathrm{~h}$ (Table 2). Detection efficiency (i.e., number of fish detected divided by 
288

289

290

291

292

293

294

295

296

297

298

299

300

301

302

303

304

305

306

307

308

309

310

number released) averaged across treatments was 47\% (range: $38-57 \%$ ) for Red Shiner, $47 \%$ (41-53\%) for Sand Shiner, and 52\% (40-63\%) for Plains Minnow. All three species were able to move upstream within the fishway (Table 3). The longest distances moved in both directions by individual Red Shiners and Plains Minnow occurred during the baseline treatment. Contrary to our expectations, these two species showed decreases in distance moved in both directions as water levels were lowered. Sand Shiner displayed the greatest downstream movement at the lowest water level (-0.15 m treatment), and the greatest upstream movement during the $-0.1 \mathrm{~m}$ treatment. Average discharge in the boat passage decreased from the baseline of $1.7 \mathrm{~m}^{-3} \cdot \mathrm{s}^{-1}$ to 1.4 during the $-0.1 \mathrm{~m}$ treatment to 0.8 during the $-0.15 \mathrm{~m}$ treatment. This decrease in flow had no measured effect of lessening fishway velocities, and we observed a subtle increase in the $-0.1 \mathrm{~m}$ and $-0.15 \mathrm{~m}$ treatments (mean $\pm \mathrm{SE}$; baseline $=0.7 \pm 0.04 \mathrm{~m} \cdot \mathrm{s}^{-1},-0.1 \mathrm{~m}=0.8 \pm 0.04$, and $-0.15 \mathrm{~m}$ $=0.8 \pm 0.04)$.

Movement into the Fishway-During VIE marking, we marked 20404 fishes across all three tagging locations. The five most abundant species tagged were Emerald Shiner (number of individuals $=10$ 117), Red Shiner (8 797), Sand Shiner (956), Channel Catfish Ictalurus punctatus (196), and Bullhead Minnow (187). We recaptured a total of 111 individuals $(<1 \%)$ consisting of three species, Red Shiner (91), Emerald Shiner (19), and Sand Shiner (1). Ninetyone fishes were recaptured across downstream sites (i.e., sites 1-6). Marked individuals of two species were recaptured in the fishway. Eight Red Shiners were recaptured in the fishway with two individuals captured in weir 7 (39 and $45 \mathrm{~mm} \mathrm{TL}$ ) and the others in weirs 3, 4, and 5. Two Emerald Shiners were recaptured, one in weir 8 (50 mm TL) and the other in weir 4 (41 mm TL). All recaptured individuals from the fishway were marked directly downstream of the dam and fishway. 

communities upstream and downstream of a dam that previously limited upstream colonization

314 by fishes. Our data show that prior to construction of the fishway, species richness was lower 315 upstream of the dam and $48 \%$ of all species collected only occurred downstream of the dam.

316 Moreover, contemporary sampling indicated a decreased magnitude in difference between 317 species richness and community structure (i.e., Bray-Curtis dissimilarity) upstream and 318 downstream of the dam. This, coupled with the consistent collection of Emerald Shiner that were 319 not present in the upstream reach prior to fishway construction suggests the structure is allowing 320 for improved continuity. However, differences in abundance and size-structure upstream and 321 downstream of the dam are still present for some species and may reflect difficulties in 322 navigating the fishway and/or impounded river upstream of the dam.

The renewed and consistent occurrence of Emerald Shiner upstream of the dam suggests this 324 species (and likely others) can successfully pass through the fishway to move upstream. Emerald 325 Shiner, a species that was historically present throughout the Arkansas River in Kansas, had been 326 restricted to the reach downstream of Wichita since the construction of small dams within the 327 City (Cross and Collins 1995; Pyron 2014). Although this species was caught regularly within 328 the fishway in our surveys, there was a dominance of larger individuals upstream of the fishway, 329 which might be a result of flows in the fishway reducing passage by smaller individuals due to 330 their reduced swimming ability (Bunt et al. 2012). Alternatively (but not exclusively), sexually 331 mature individuals of some species might be more mobile. Emerald Shiner do not reach sexual 332 maturity until $55 \mathrm{~mm}$ TL (Flitner 1964) and the median size of fish upstream was $61 \mathrm{~mm}(\mathrm{IQR}=$ $33354-67 \mathrm{~mm}$ ). Thus, these larger mature individuals might be more able or driven to move 
334 upstream than their smaller conspecifics. Assessing the effects of the fishway on size-structure of

335 other species is more ambiguous. Red Shiner and Sand Shiner displayed no difference (or

336 marginally smaller fish upstream) in size-structure upstream and downstream of the dam.

337 However, these species continuously occurred upstream of the dam prior to the fishway

338 suggesting that connectivity might be less important for their persistence. Red Shiner and Sand

339 Shiner can reach sexual maturity at $30 \mathrm{~mm}$ standard length (Kansas Fishes Committee 2014),

340 and a marked $39 \mathrm{~mm}$ TL Red Shiner was collected in the upper portions of the fishway. The

341 movement of this relatively small fish in the fishway suggests smaller individuals can navigate

342 flows in the fishway.

The Lincoln Street Fishway is likely to pass many species in the community. Although our 344 study did not directly measure successful ascension (i.e., a marked fish released at the entrance 345 recaptured at the exit or upstream), we did document 29 species within the structure showing that 346 a majority $(74 \%)$ of the species in the entire sampled riverine community used the fishway in

347 some fashion. Recently, the importance of multi-species fishways has been expressed, and 348 several efforts documenting community use of fishways have taken place. A vertical-slot 349 fishway (i.e., a series of baffles each with a vertical slot) passed 11 species on a lowland river in 350 Australia (Stuart et al. 2008). Two vertical-slot fishways in Belgium passed 14 and 22 species, 351 respectively (Benitez et al. 2015). Both of these case studies provide evidence of successful 352 ascension of fishways by multiple species within a fish community and a range of sizes within 353 populations. Fishes ranging in size from 20-1150 mm TL were captured in the Lincoln Street 354 Fishway, and Longnose Gar Lepisosteus osseus were observed moving upstream through the 355 high velocities $\left(>2 \mathrm{~m} \cdot \mathrm{s}^{-1}\right)$ of the boat passage (C. Pennock, personal observation). Thus, this 
356 fishway potentially has the capacity to restore connectivity for multiple species and for multiple

357 life-stages.

Pre-fishway communities were different in community structure and richness because extirpations of several species occurred upstream of the dam (e.g., Emerald Shiner, Plains Minnow; Perkin et al. 2015), but populations persisted downstream. The recent absence of Plains Minnow and Peppered Chub Macrhybopsis tetranema (Pennock et al. 2017) from downstream, and the recolonization of Emerald Shiner to upstream are contributing to the observed contemporary homogenization between upstream and downstream communities. Similar to our study, other works have shown delayed, albeit improving, changes in community structure 365 following the installation of fishways (Gilligan et al. 2003). Whereas the Lincoln Street Fishway 366 has allowed for improved continuity of the Arkansas River fish community, residual habitat 367 deficiencies might be preventing full recovery of community integrity.

Fishways restore the structural connectivity of rivers for fishes (i.e., allowing for the potential 369 for movement), but whether they restore functional connectivity (i.e., fish actually moving 370 upstream without negative physiological or fitness consequences) requires more attention 371 (McLaughlin et al. 2013). A potential problem with fishways is that they do not fully remedy the 372 problem and habitat deficiencies upstream may still limit the restoration of functional 373 connectivity (Brown et al. 2013; Kemp 2016). Moreover, if fishways entice fish (e.g., fishway 374 flows attract rheophilic fishes) to move into suboptimal habitat above dams, this can lead to 375 reduced fitness for populations (i.e., an ecological trap; Pelicice and Agostinho 2008).

376 Specifically, the Lincoln Street Dam still impounds the river for $3 \mathrm{rkm}$ upstream creating a lentic 377 habitat in which we found overall decreased abundance and richness relative to sites with lotic 378 habitat. This lacustrine zone upstream of the fishway might negatively impact fishes that have 
379 successfully ascended the fishway by discouraging further upstream movement or allowing for 380 increased predation risk by piscivorous fishes. Indeed in our study, sites in the impounded reach

381 (i.e., 7, 8, and 9) had the highest abundance of predatory fishes (e.g., Largemouth Bass

382 Micropterus salmoides, Green Sunfish Lepomis cyanellus, and Flathead Catfish Pylodictis

383 olivaris). Thus, despite the fishway restoring movement corridors for adults, $3 \mathrm{rkm}$ of impounded

384 water might still be detrimental to egg or larval survival either through increased predation or 385 allowing eggs and larvae to fall out of suspension. Additionally, another low-head dam exists 9 386 rkm upstream that likely impedes further upstream movement by fishes.

387 388 389 390 391

392

Over the course of our study it was clear that both water level management and maintenance of the fishway play critical roles in allowing effective passage of fishes. Specifically, obstruction of fishway entrances by debris and sediments can impact performance by changing hydrology, or creating behavioral or physical barriers. Thus, fishways require regular inspection and maintenance to confirm optimal functionality (O’Connor et al. 2015). A possible explanation for the decrease in abundance of individuals and species richness in the Lincoln Street Fishway over the course of our study might be attributed to the lower portions of the fishway filling with sediments after high flow events in 2015. Sediments completely filled the first $20-30 \mathrm{~m}$ on both sides of the fishway, effectively moving the entrance of the fishway upstream. Another aspect of the Lincoln Street Dam that might have influenced passage and community composition within the fishway is its hydraulically controllable panels. This feature of the dam allows the City to adjust impounded water levels upstream. Because the fishway is built alongside and is connected to the dam, flows through the fishway are linked to the impounded water level upstream. If the water level upstream is lowered beyond $1.2 \mathrm{~m}$, flow ceases through the fishway. Over the course of our study the dam was lowered such that the fishway stopped flowing on 11 separate 
402

403

404

405

406

407

408

409

410

411

412

413

414

415

416

417

occasions. During these occasions the fishway was dry for 1-76 consecutive days. The fishway was not flowing for a total of 106 days during 2015 (Jan.-Dec.) and 39 days in 2016 (Jan.-Aug.).

The Lincoln Street Fishway is a potential means to restore access to habitat for fishes that need long, connected reaches of river. In the Great Plains, pelagic-spawning minnows rely on connectivity and adequate seasonal flows to complete their life-history (Bottrell et al. 1964; Dudley and Platania 2007; Wilde and Durham 2008; Perkin and Gido 2011). There are many reaches where these fishes have been extirpated across the Great Plains, including our study reach (Perkin and Gido 2011; Perkin et al. 2015; Pennock et al. 2017). Thus, the Lincoln Street Fishway might have been constructed too late to recover these species. Although our data is suggestive that pelagic-spawning minnows could benefit from the installation of fishways at dams inhibiting their movement, repatriation in reaches where they have been extirpated is a necessary first step towards community recovery. Restoration of adequate riverine habitat and repatriation to reaches of river from which species have been extirpated is needed across the Great Plains to ensure the long-term persistence of endemic species reliant on connectivity and seasonal flow variation.

\section{Acknowledgements}

We would like to thank Jim Hardesty, Neil Vyff, Terry Kelley, Mark Hall, and Larry Hoetmer of the City of Wichita for their assistance throughout the study. Additionally, for help during data collection and tagging efforts we want to thank S. Hedden, M. Waters, R. Webber, Z.

Cordes, J. Wellemeyer, C. Hedden, T. Fanshier, G. Hopper, B. Frenette, B. Scharping, B. Kerr, J. Conley, and the KDWPT Stream Survey and Assessment Crews of 2015 and 2016. P.

MacKinnon and M. Brower provided valuable technical expertise and advice on PIT antenna operation. Funding for this project was provided by a U.S. Fish and Wildlife Service State 
425 Wildlife Grant administered through the Ecological Services Section, KDWPT. This study was

426 approved by the Kansas State University Institutional Animal Care and Use Committee (protocol

427 \#3676). M. Tobler, J. Perkin, the associate editor, and two anonymous reviewers provided

428 insightful comments that improved this manuscript.

429

430

References

431

432

433

434

435

436

437

438

439

440

441

442

443

444

Anderson, M.J. 2001. A new method for non-parametric multivariate analysis of variance. Aust. Ecol. 26: 32-46.

Archdeacon, T.P. and Remshardt, W.J. 2012. Observations of hatchery-reared Rio Grande Silvery Minnow using a fishway. N. Am. J. Fish. Manage. 32: 648-655.

Bates, D., Maechler, M., Bolker, B., and Walker, S. 2015. Fitting linear mixed-effects models using lme4. J. Stat. Softw. 67: 1-48.

Benitez, J.P., Matondo, B.N., Dierckx, A., and Ovidio, M. 2015. An overview of potamodromous fish upstream movements in medium-sized rivers, by means of fish passes monitoring. Aquat. Ecol. 49: 481-497.

Boiten, W. and Dommerholt, A. 2006. Standard design of the Dutch pool and orifice fishway. International Journal of River Basin Management 4: 219-227.

Bottrell, C.E., Ingersol, R.H., and Jones, R.W. 1964. Notes on the embryology, early development, and behavior of Hybopsis aestivalis tetranemus (Gilbert). Trans. Am. Microsc. Soc. 83: 391-399. 
445 446

447

448

449

450

451

452

453

454

455

456

457

458

459

460

461

462

463

464

465

Bray, J.R. and Curtis, J.T. 1957. An ordination of the upland forest communities of southern Wisconsin. Ecol. Monogr. 27: 325-349.

Brown, J.J., Limburg, K.E., Waldman, J.R., Stephenson, K., Glenn, E.P., Juanes, F. and Jordaan, A. 2013. Fish and hydropower on the U.S. Atlantic coast: failed fisheries policies from half-way technologies. Conserv. Lett. 6: 280-286.

Bunt, C.M., Castro-Santos, T., and Haro, A. 2012. Performance of fish passage structures at upstream barriers to migration. River Res. Appl. 28: 457-478.

Cross, F.B. and Collins, J.T. 1995. Fishes in Kansas. University Press of Kansas, Lawrence.

Cross, F.B., Moss, R.E., and Collins, J.T. 1985. Assessment of dewatering impacts on stream fisheries in the Arkansas and Cimarron rivers. Museum of Natural History University of Kansas, Lawrence.

Dodds, W.K., Gido, K.B., Whiles, M.R., Fritz, K.M, and Matthews, W.J. 2004. Life on the edge: the ecology of Great Plains prairie streams. BioScience 54: 205-216.

Dudley, R.K. and Platania, S.P. 2007. Flow regulation and fragmentation imperil pelagicspawning riverine fishes. Ecol. Appl. 17: 2074-2086.

Fausch, K.D. and Bestgen, K.R. 1997. Ecology of fishes indigenous to the central and southwestern Great Plains. In Ecology and conservation of Great Plains vertebrates. Edited by F.L. Knopf and F.B. Samson. Springer, New York. pp. 131-166.

Ficke, A.D. and Myrick, C.A. 2007. Fish barriers and small plains fishes: fishway design recommendation and the impact of existing instream structures. Final Project Report, Colorado Division of Wildlife Contract Number IA-CSU-1190-2004, CSU Number 5- 
30216. Department of Fish, Wildlife, and Conservation Biology, Colorado State University, Fort Collins.

Flitner, G.A. 1964. Morphometry and life history of the emerald shiner Notropis atherinoides Rafinesque. PhD dissertation. University of Michigan, Ann Arbor.

Fullerton, A.H., Burnett, K.M., Steel, E.A., Flitcroft, R.L., Pess, G.R., Feist, B.E., Torgersen, C.E., Miller, D.J., and Sanderson, B.L. 2010. Hydrological connectivity for riverine fish: measurement challenges and research opportunities. Freshwater Biol. 55: 2215-2237.

Gillette, D.P., Tiemann, J.S., Edds, D.R., and Wildhaber, M.L. 2005. Spatiotemporal patterns of fish assemblage structure in a river impounded by low-head dams. Copeia 2005: 539-549.

Gilligan, D.M., Harris, J.H., and Mallen-Cooper, M. 2003. Monitoring changes in Crawford River fish community following replacement of an ineffective fishway with a verticalslot fishway design: results of an eight year monitoring program. NSW Fisheries Final Report Series No. 45, NSW Fisheries Office of Conservation, NSW Fisheries Centre, Narrandera NSW, Australia.

Hoagstrom, C.W. and T.F. Turner. 2015. Recruitment ecology of pelagic-broadcast spawning minnows: paradigms from the ocean advance science and conservation of an imperiled freshwater fauna. Fish and Fish. 16:282-299.

Kansas Fishes Committee. 2014. Kansas Fishes. University Press of Kansas, Lawrence.

Kemp, P.S. 2016. Meta-analyses, metrics and motivation: mixed messages in the fish passage debate. River Res. Appl. 32: 2116-2124. 
Luttrell, G.R., Echelle, A.A., Fisher, W.L., and Eisenhour, D.J. 1999. Declining status of two species of the Macrhybopsis aestivalis complex (Teleostei: Cyprinidae) in the Arkansas River Basin and related effects of reservoirs as barriers to dispersal. Copeia 1999: 981989.

McLaughlin, R.L., Smyth, E.R.B., Castro-Santos, T., Jones, M.L., Koops, M.A., Pratt, T.C., and Vélez-Espino, L. 2013. Unintended consequences and trade-offs of fish passage. Fish. Fish. 14: 580-604.

Moore, G.A. 1944. Notes on the early life history of Notropis girardi. Copeia 1944: 209-214.

Neumann, R. M. and Allen, M.S. 2007. Size structure. In Analysis and interpretation of freshwater fisheries data. Edited by C.S. Guy and M.L. Brown. American Fisheries Society, Bethesda, Maryland. pp. 375-421.

O’Connor, J., Mallen-Cooper, M., and Stuart, I. 2015. Performance, operation and maintenance guidelines for fishway and fish passage works. Technical Report Series No. 262, Water and Catchment Group, Department of Environment, Land, Water, and Planning, Arthur Rylah Institute for Environmental Research, Heidelberg, Victoria, Australia.

O’Hanley, J.R., Wright, J., Diebel, M., Fedora, M.A., and Soucy, C.L. 2013. Restoring stream habitat connectivity: a proposed method for prioritizing the removal of resident fish passage barriers. J. of Environ. Manage. 125:19-27.

Oksanen, J., Blanchet, F.G., Friendly, M., Kindt, R., Legendre, P., McGlinn, D., Minchin, P.R., O’Hara, R.B., Simpson, G.L., Solymos, P., Stevens, M.H.H., Szoecs, E., and Wagner, H. 2016. vegan: Community ecology package. R package verson 2. 4-1. http://CRAN.Rproject.org/package=vegan. 
508 509

510 511

512 513 514 515 516

Pelicice, F.M. and Agostinho, A.A. 2008. Fish-passage facilities as ecological traps in large Neotropical rivers. Conserv. Biol. 22: 180-188.

Perkin, J.S. and Gido, K.B. 2011. Stream fragmentation thresholds for a reproductive guild of Great Plains fishes. Fisheries 36: 371-383.

Perkin, J.S. and Gido, K.B. 2012. Fragmentation alters stream fish community structure in dendritic ecological networks. Ecol. Appl. 22: 2176-2187.

Perkin, J.S., Gido, K.B., Costigan, K.H., Daniels, M.D., and Johnson, E.R. 2015. Fragmentation and drying ratchet down Great Plains stream fish diversity. Aquat. Conserv. Mar. Freshw. Ecosyst. 25: 639-655.

Pennock, C.A. 2017. Beautification of Great Plains rivers: a perspective on the use and appreciate of aquatic resources. Fisheries 42: 83-87.

Pennock, C.A. In press. Effects of PIT tags on Red Shiner Cyprinella lutrensis and Sand Shiner Notropis stramineus. Trans. Kans. Acad. Sci.

Pennock, C.A., Frenette, B.D., Waters, M.J., and Gido, K.B. 2016. Survival of and tag retention in Southern Redbelly Dace injected with two sizes of PIT tags. N. Am. J. Fish. Manage. 36: 1386-1394.

Pennock, C.A., Gido, K.B., Perkin, J.S., Weaver, V.D., Davenport, S.R., and Caldwell, J.M. 2017. Collapsing range of an endemic Great Plains minnow, Peppered Chub Macrhybopsis tetranema. Am. Midl. Nat. 177: 57-68.

Pompeu, P.S., Agostinho, A.A., and Pelicice, F.M. 2012. Existing and future challenges: the concept of successful fish passage in South America. River Res. Appl. 28: 504-512. 
529 Pyron, M. 2014. Emerald Shiner, Notropis atherinoides Rafinesque 1818. In Kansas Fishes.

530 Edited by Kansas Fishes Committee. University Press of Kansas, Lawrence. pp. 199-200.

531 R Core Team. 2016. R: a language for statistical computing. R Foundation for Statistical

532 Computing, Vienna, Austria. URL https://www.R-project.org/.

533 Stuart, I.G., Zampatt, B.P., and Baumgartner, L.J. 2008. Can a low-gradient vertical slot fishway 534 provide passage for a lowland river fish community? Mar. Freshwater Res. 59: 332-346.

535 Weaver, V. D. 1993. Effects of urban pollution on sand shiners (Notropis stramineus) and the 536

Wilde, G.R. and Durham, B.W. 2008. A life history model for Peppered Chub, a broadcastuse of genetic variation as a molecular bioindicator for aquatic ecosystems. Masters thesis. Wichita State University, Kansas. spawning cyprinid. Trans. Am. Fish. Soc. 137: 1657-1666.

Winston, M.R., Taylor, C.M., and Pigg, J. 1991. Upstream extirpation of four minnow species due to damming of a prairie stream. Trans. Am. Fish. Soc. 120: 98-105.

542 Zuur, A.F., Ieno, E.N., Walker, N.J., Saveliev, A.A., and Smith, G.M. 2009. Mixed effects models and extensions in ecology with R. Springer, New York. 
545 Table 1: Number of individuals collected during sampling up- and downstream of the Lincoln

546 Street Dam and pre- and post-fishway construction and in the fishway structure on the Arkansas

547 River in Wichita, Kansas. Sampling pre-fishway used a combination of tote barge electrofishing

548 and seining and post-fishway sampling only used seining. Species of conservation concern (i.e.,

549 threatened or endangered) within Kansas are denoted with a T or E.

\begin{tabular}{|c|c|c|c|c|c|c|c|}
\hline \multirow[b]{2}{*}{ Common Name } & \multirow[b]{2}{*}{ Scientific Name } & \multicolumn{4}{|c|}{ Time Period and Location } & \multicolumn{2}{|c|}{ Fishway } \\
\hline & & $\begin{array}{c}\text { Pre } \\
\text { Down }\end{array}$ & $\begin{array}{l}\text { Pre } \\
\text { Up }\end{array}$ & $\begin{array}{c}\text { Post } \\
\text { Down }\end{array}$ & $\begin{array}{l}\text { Post } \\
\text { Up } \\
\end{array}$ & 2015 & 2016 \\
\hline Black Bullhead & Ameiurus melas & 2 & & & & 4 & \\
\hline Freshwater Drum & Aplodinotus grunniens & 192 & & 36 & 2 & 11 & 5 \\
\hline Goldfish & Carassius auratus & 4 & 2 & 1 & 1 & 4 & 3 \\
\hline River Carpsucker & Carpiodes carpio & 2319 & 61 & 51 & 62 & 14 & 12 \\
\hline Quillback & Carpiodes cyprinus & 281 & 4 & 4 & 6 & 5 & \\
\hline Common Carp & Cyprinus carpio & 866 & 58 & 11 & 18 & 5 & 4 \\
\hline Red Shiner & Cyprinella lutrensis & 28889 & 12666 & 46632 & 31888 & 2347 & 2744 \\
\hline Gizzard Shad & Dorosoma cepedianum & 3553 & 15 & 59 & 55 & 82 & 1 \\
\hline Northern Plains Killifish & Fundulus kansae & 67 & 76 & 171 & 103 & & \\
\hline Western Mosquitofish & Gambusia affinis & 318 & 1385 & 11 & 29 & 2 & \\
\hline Plains Minnow $(\mathrm{T})$ & Hybognathus placitus & 41 & & & & & \\
\hline Smallmouth Buffalo & Ictiobus bubalus & 108 & & 5 & 2 & & \\
\hline Black Buffalo & Ictiobus niger & 67 & & 5 & & & \\
\hline Channel Catfish & Ictalurus punctatus & 1879 & 128 & 1792 & 1683 & 317 & 412 \\
\hline Brook Silverside & Labidesthes sicculus & 20 & & & & & \\
\hline Green Sunfish & Lepomis cyanellus & 238 & 18 & 1 & 94 & 11 & 2 \\
\hline Orangespotted Sunfish & Lepomis humilis & 647 & 50 & 22 & 39 & 81 & 2 \\
\hline Bluegill & Lepomis macrochirus & 270 & 6 & 22 & 25 & 89 & 1 \\
\hline Longear Sunfish & Lepomis megalotis & 348 & 7 & 9 & 52 & 59 & 8 \\
\hline Longnose Gar & Lepisosteus osseus & 41 & & 17 & 6 & 1 & 1 \\
\hline Shortnose Gar & Lepisosteus platostomus & 7 & & 1 & & & \\
\hline Silver Chub (E) & Macrhybopsis storeriana & 87 & & 8 & & & \\
\hline Peppered Chub (E) & Macrhybopsis tetranema & 118 & & & & & \\
\hline Largemouth Bass & Micropterus salmoides & 80 & 11 & 4 & 14 & 2 & 1 \\
\hline White Perch & Morone americana & 14 & & & & 9 & \\
\hline White Bass & Morone chrysops & 44 & & 2 & & & \\
\hline Palmetto Bass (Wiper) & Morone chrysops $x$ saxatilis & 54 & & 4 & & & \\
\hline Pealip Redhorse & Moxostoma pisolabrum & 185 & 2 & 4 & 1 & & \\
\hline Golden Shiner & Notemigonus crysoleucas & 13 & 2 & & 2 & & \\
\hline Emerald Shiner & Notropis atherinoides & 17548 & & 20616 & 1046 & 8941 & 1858 \\
\hline
\end{tabular}




\begin{tabular}{|c|c|c|c|c|c|c|c|}
\hline Ghost Shiner & Notropis buchanani & & & 2 & & 4 & \\
\hline Sand Shiner & Notropis stramineus & 7023 & 5587 & 11712 & 5229 & 3937 & 159 \\
\hline Ozark Logperch & Percina caprodes & 12 & & & & & 6 \\
\hline Slenderhead Darter & Percina phoxocephala & 112 & 1 & 20 & 11 & & 12 \\
\hline Suckermouth Minnow & Phenacobius mirabilis & 441 & 30 & 247 & 112 & 11 & 47 \\
\hline Fathead Minnow & Pimephales promelas & 112 & 31 & 15 & 11 & 3 & 4 \\
\hline Bullhead Minnow & Pimephales vigilax & 1466 & 196 & 736 & 1158 & 259 & 263 \\
\hline White Crappie & Pomoxis annularis & 28 & & 4 & 2 & 13 & 3 \\
\hline Flathead Catfish & Pylodictis olivaris & 112 & 20 & 4 & 13 & 1 & 4 \\
\hline \multicolumn{2}{|l|}{ Other species captured ${ }^{\mathrm{a}}$} & 14 & & 2 & 4 & 2 & 1 \\
\hline \multicolumn{2}{|c|}{ Total Number of Individuals } & 67620 & 20356 & 82230 & 41668 & 34214 & 5553 \\
\hline
\end{tabular}

${ }^{\mathrm{a}}$ Species with $<5$ individuals captured: Central Stoneroller Campostoma anomalum, Grass Carp Ctenopharyngodon idella, Arkansas Darter (T) Etheostoma cragini, Bigmouth Buffalo Ictiobus cyprinellus, Striped Bass Morone saxatilis, Golden Redhorse Moxostoma erythrurum, Carmine Shiner Notropis percobromus, Channel Darter Percina copelandi, Bluntnose Minnow Pimephales notatus, Black Crappie Pomoxis nigromaculatus, Walleye Sander vitreus. 
552 Table 2: Number of fish released, percent tag retention, and percent survival of fish tagged with 553 passive integrated transponder tags over $24 \mathrm{~h}$. Fish were released in May and June.

\begin{tabular}{ccccc}
\hline & $\begin{array}{c}\text { Water } \\
\text { level } \\
\text { Species }\end{array}$ & $\begin{array}{c}\text { Number } \\
\text { released }\end{array}$ & $\begin{array}{c}\text { Percent } \\
\text { retention }\end{array}$ & $\begin{array}{c}\text { Percent } \\
\text { survival }\end{array}$ \\
\hline Red Shiner & Baseline & 92 & 100 & 93 \\
& $-0.1 \mathrm{~m}$ & 96 & 100 & 100 \\
& $-0.15 \mathrm{~m}$ & 93 & 99 & 100 \\
Sand Shiner & Baseline & 94 & 100 & 97 \\
& $-0.1 \mathrm{~m}$ & 91 & 100 & 97 \\
& $-0.15 \mathrm{~m}$ & 99 & 100 & 97 \\
Plains Minnow & Baseline & 65 & 100 & 98 \\
& $-0.1 \mathrm{~m}$ & 30 & 100 & 100 \\
\hline
\end{tabular}


554 Table 3: Mean distances $(\mathrm{m} ; \pm \mathrm{SD})$ moved from a release point by detected fish in the fishway during an experiment that manipulated

555 the water levels in the fishway. Numbers in parenthesis represent the maximum distance moved by any individual in a given direction

556 during each treatment.

\begin{tabular}{lcccccc} 
& \multicolumn{2}{c}{ Red Shiner } & \multicolumn{2}{c}{ Sand Shiner } & \multicolumn{2}{c}{ Plains Minnow } \\
\cline { 2 - 7 } $\begin{array}{c}\text { Water level } \\
\text { treatment }\end{array}$ & Downstream & Upstream & Downstream & Upstream & Downstream & Upstream \\
\hline Baseline & $2.90 \pm 3.14(16)$ & $2.85 \pm 2.71(13)$ & $2.06 \pm 1.06(5)$ & $1.11 \pm 0.33(2)$ & $4.56 \pm 5.86(24)$ & $3.65 \pm 5.51(26)$ \\
$-0.10 \mathrm{~m}$ & $2.91 \pm 2.66(13)$ & $1(1)$ & $3.09 \pm 2.38(13)$ & $8.5 \pm 10.6(16)$ & $1.78 \pm 0.67(3)$ & $1.56 \pm 1.33(5)$ \\
$-0.15 \mathrm{~m}$ & $1.91 \pm 1.28(7)$ & $2.29 \pm 1.36(5)$ & $2.39 \pm 2.35(18)$ & $1.5 \pm 0.71(2)$ & --- & --- \\
Grand Mean & $2.50 \pm 2.39$ & $2.50 \pm 2.23$ & $2.53 \pm 2.13$ & $2.31 \pm 4.13$ & $3.82 \pm 5.16$ & $3.11 \pm 4.86$ \\
\hline
\end{tabular}




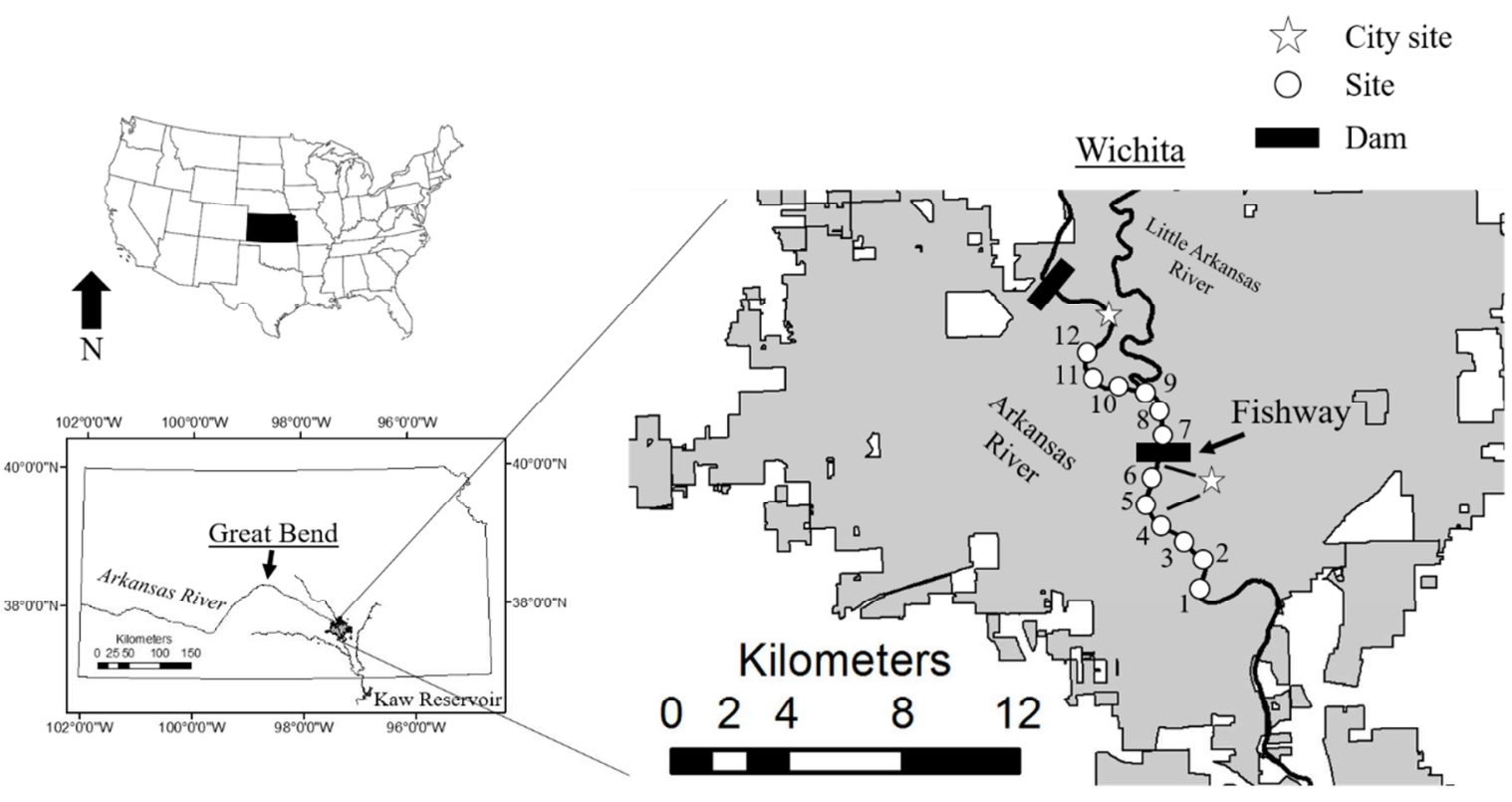

Figure 1: Study area map displaying the spatial arrangement and labeling scheme of sites (inset)

561 sampled during 2015-2016 after construction of the Lincoln Street Dam and Fishway on the

562 Arkansas River in Wichita, Kansas. Three sites sampled by the City of Wichita are also depicted.

563 Within the study area the river is fragmented by two low-head dams, and flows into Kaw

564 Reservoir upon entering Oklahoma. 


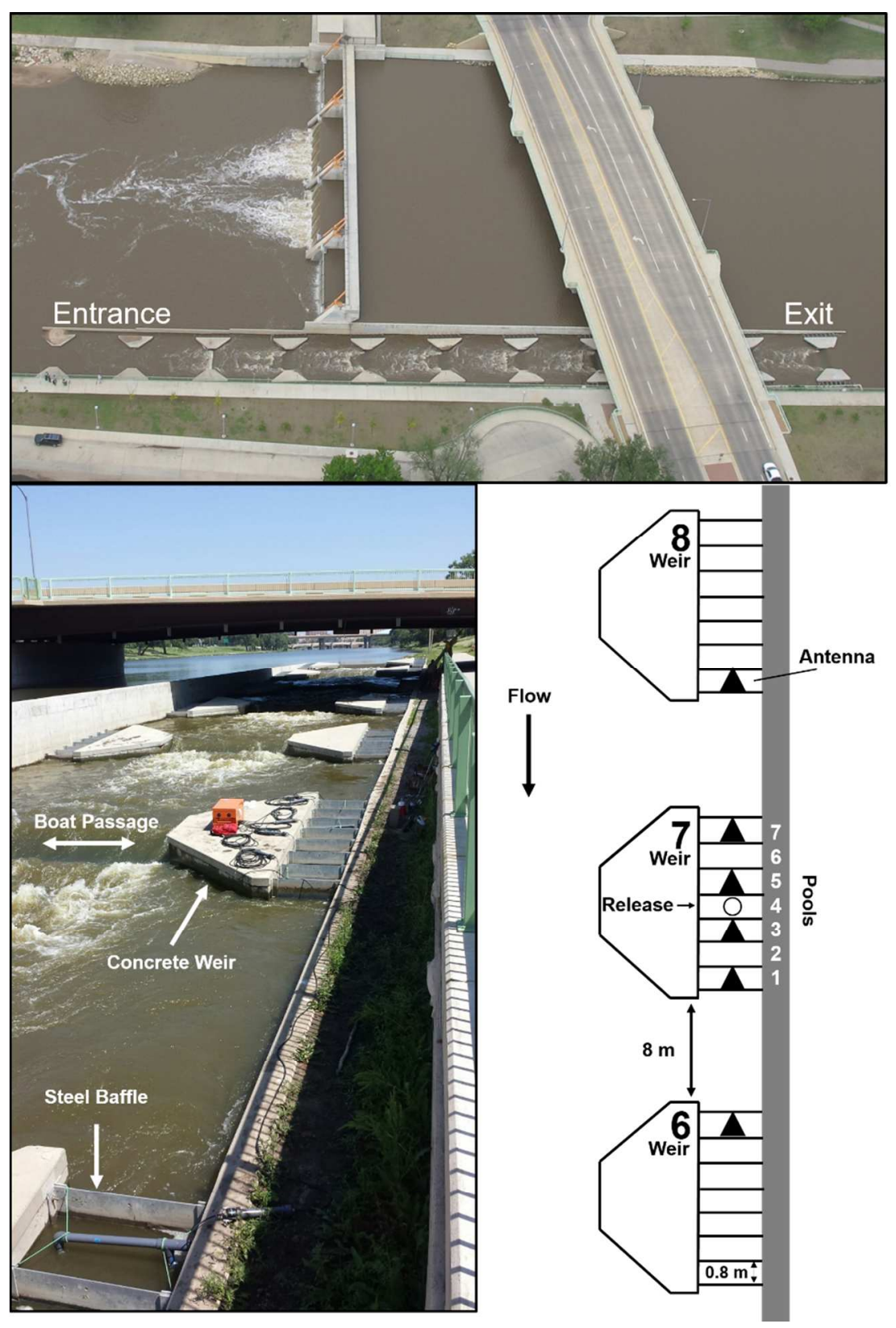

567 Figure 2: Areal and lateral views of the Lincoln Street Dam and Fishway on the Arkansas River

568 in Wichita, Kansas. Dutch Pool and Orifice fishways are located on either side of a central boat

569 passage and the downstream entrance and upstream exit labeled in the top photograph. Stationary

570 antenna were placed within the fishway during experiments that manipulated water levels

571 upstream of the dam to assess the movement response of fishes. Weirs are numbered from the 
572 entrance (downstream) to the exit (upstream) of the fishway. Photo credits: top) R. Schultheis,

573 KDWPT; bottom) C.A. Pennock.

574
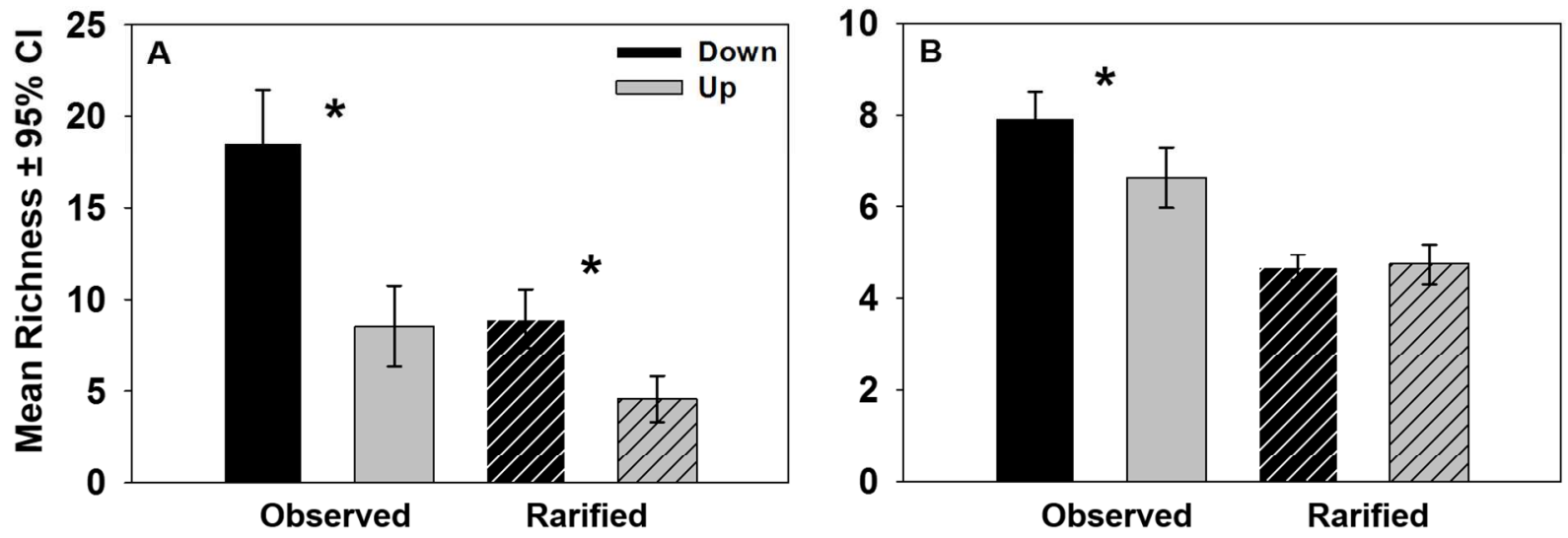

575

576 Figure 3: Comparison of mean $( \pm 95 \mathrm{CI})$ observed and rarified fish species richness upstream

577 and downstream of the Lincoln Street Dam based on sampling by A) the City of Wichita prior to

578 construction of the fishway and B) contemporary sampling from this study. Samples were

579 rarified to 100 individuals. Asterisks denote significant $(P<0.05)$ differences. 

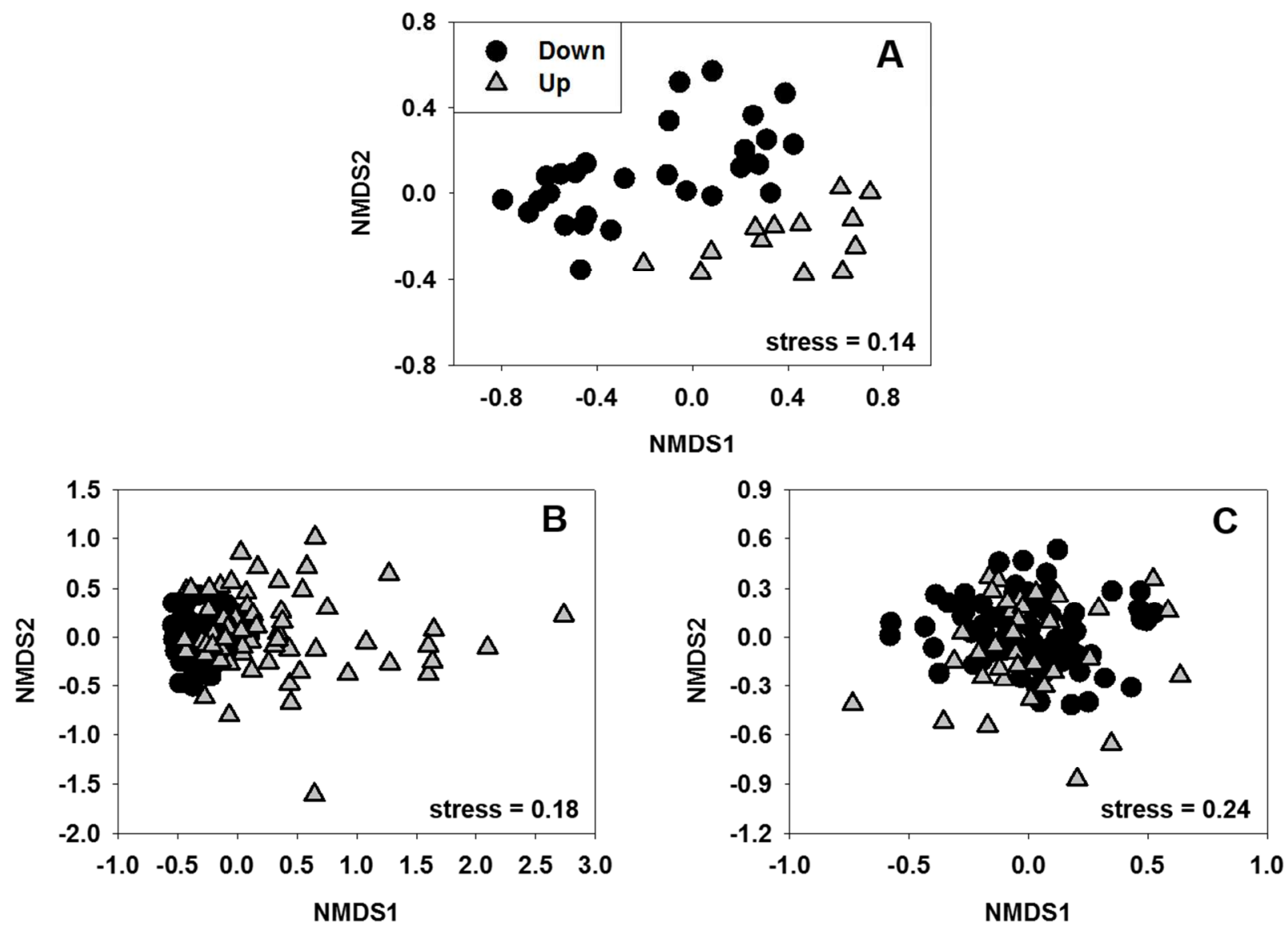

582 Figure 4: Non-metric multidimensional scaling ordinations of Bray-Curtis dissimilarity (Bray

583 and Curtis 1957) using $4^{\text {th }}$ root transformed abundance from fish communities sampled

584 downstream (Down) and upstream (Up) of the dam prior to (A) and after (B) a fishway was built

585 on the Arkansas River at the Lincoln Street Dam in Wichita, Kansas. Statistical comparisons

586 between downstream and upstream communities were all significant (pMANOVA: $P<0.001$ ).

587 Contemporary communities are significantly different regardless of whether all sites are

588 considered (B) or if the lentic sites $(7,8$, and 9), where sampling effort varied compared to lotic 589 sites, are excluded (C). 


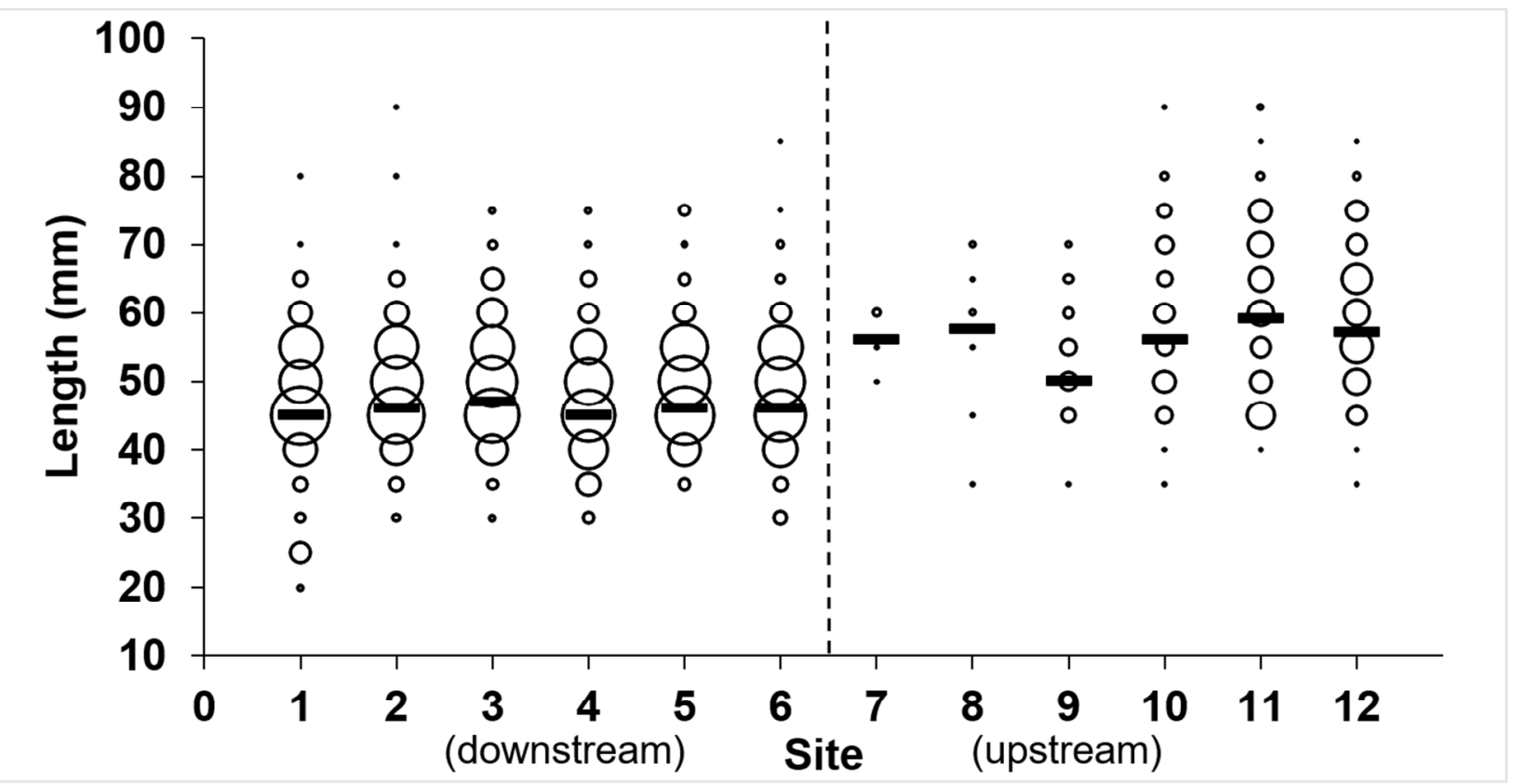

591 Figure 5: Length-frequencies of Emerald Shiner collected from 12 sampling sites. Dam location

592 relative to site locations is represented by the dashed line. The area of a circle is proportional to

593 the relative catch of $5 \mathrm{~mm}$ size classes ranging from 20-90 $\mathrm{mm}$ TL across all sites. Horizontal

594 bars represent the median length at each site. The number of individuals was significantly higher

595 downstream $(P<0.001$, mean $=314$ fish $)$ compared to upstream (mean $=37$ fish $)$. Median length

596 was significantly higher upstream $(P<0.001$, median $=61 \mathrm{~mm})$ compared to downstream

$597 \quad($ median $=47 \mathrm{~mm})$. 

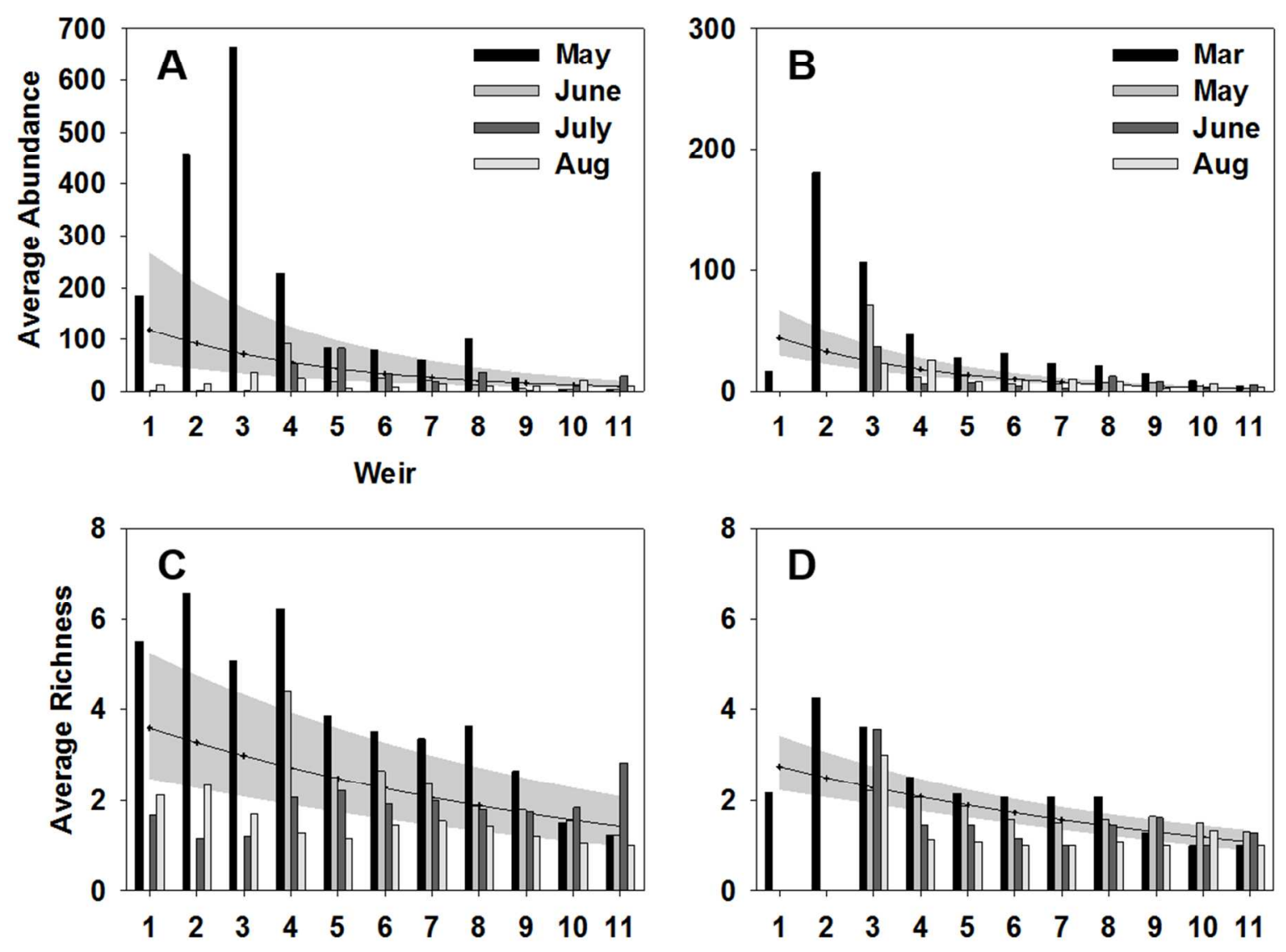

Figure 6: Number of individuals (abundance) declined significantly with increasing distance

601 upstream (weir) within the fishway in both 2015 (A) and 2016 (B). Y-axes differ between panels.

602 Species occurrence (richness) showed a similar trend in 2015 (C) and 2016 (D) as abundance.

603 Lines and confidence regions represent marginal estimates with 95\% confidence intervals from

604 generalized linear mixed models with a Poisson distribution using Weir number as a fixed effect

605 and Month as a random effect. All relationships were significant $(P<0.001)$. 